\title{
Biostratigraphic and Lithostratigraphic Study of Fahliyan Formation in Kuh-E-Siah (Arsenjan Area, North-East of Fars Province)
}

\author{
Masoud Abedpour ${ }^{1,2}$, Massih Afghah2*, Vahid Ahmadi², Mohammadsadegh Dehghanian ${ }^{3}$ \\ ${ }^{1}$ Department of Geology, College Fars Science and Research Branch, Islamic Azad University, Fars, Iran \\ ${ }^{2}$ Department of Geology, Shiraz Branch, Islamic Azad University, Shiraz, Iran \\ ${ }^{3}$ Department of Geology, Bandar Abbas Branch, Islamic Azad University, Bandar Abbas, Iran \\ Email: MA_493@yahoo.com, ^massihafg2002@yahoo.com,V_ahmadi_geo@yahoo.com, msadeghdehghanian@gmail.com
}

How to cite this paper: Abedpour, M., Afghah, M., Ahmadi, V. and Dehghanian, M. (2016) Biostratigraphic and Lithostratigraphic Study of Fahliyan Formation in Kuh-E-Siah (Arsenjan Area, North-East of Fars Province). Open Journal of Geology, 6, 1605-1618.

http://dx.doi.org/10.4236/ojg.2016.612114

Received: October 26, 2016

Accepted: December 26, 2016

Published: December 29, 2016

Copyright $\odot 2016$ by authors and Scientific Research Publishing Inc. This work is licensed under the Creative Commons Attribution International License (CC BY 4.0).

http://creativecommons.org/licenses/by/4.0/

\section{Abstract}

Fahliyan Formation is importance in terms of Zagros stratigraphy since it is one of the oil reservoir rocks at the Jurassic-Cretaceous boundary. This rock unit consists of two types of deep and shallow facies in Zagros area. Recognition of bio-zones as well as discontinuity or continuity between the studied formation and the encompassed strata is taken into consideration. In order to study biostratigraphy on Fahliyan Formation, the stratigraphic section of Kuh-e-siah in the north-east of Fars Province was selected. In this section, Fahliyan Formation is measured $345 \mathrm{~m}$ consisting of thin to medium-bedded of limestone with the interbeds of sandy and dolomitic limestones. Fahliyan Formation conformably overlies Surmeh formation and underlies the marls of Gadvan formation. Vertical distribution of the identified foraminifers and calcareous algae confirms presence of 3 biozones in the sediments of Fahliyan Formation, as follows: 1) Calpionella alpina zone, 2) Pseudochrysalidina conica zone, 3) Pseudocyclammina lituus-Trocholina sp. assemblage zone. Based on Established biozones, the age of Fahliyan Formation in Kuh-e-Siah section was determined from Berriasian to Late Hauterivian.

\section{Keywords}

Biostratigraphy, Lithostratigraphy, Fahliyan, Zagros, Iran

\section{Introduction}

Neocomian and Barremian sediments in Persian Gulf and Zagros area have been introduced with Fahliyan, Gadvan and Garau Formations. These sediments in Zagros area have changed in terms of bio and lithofacies, laterally during the Neocomian age, 
confirming the tectonic $t$ and paleogeographical settings of the Zagros basin. Thus, the mentioned sediments with shale neritic, carbonate, hemipellagic and pellagic facies in Fars, south of Dezful and southeast of Persian Gulf and with Fahliyan and Gadvan Formations in the north of Dezful embayment, Lorestan and north-west of Persian Gulf have been introduced as Garau, Fahliyan and Gadvan Formations, respectively.

Studying the Biostratigraphy of the Jurassic-Cretaceous sequence reveals regression between the mentioned strata in different parts of Zagros as well as its better comparison with other regions in the Arabian Plate Aghanabati A. (1998) [1].

Facies analysis of the Jurassic-Cretaceous succession, determining the relationship between the sequences formed by the sea-level fluctuation, tectonic setting, rate of sediment supply and age determination of the mentioned strata based on the bio and lithofacies would make it possible to present the sedimentary model and establish a conformity between the currently set sequences and other parts of the Iranian and Arabian Plates.

Since studies on Fahliyan Formation have been focused on the oil-rich regions of southern Iran and there are few studies at this level on biostratigraphy, microfacies and sedimentary environment of Fahliyan Formation in the interior and coastal Fars, e.g. Abyat et al. (2016), Abyat et al. (2014), Abyat et al. (2013) [2] [3] and Afghah (2006) [4].

\section{Methods and Materials}

In order to study biostratigraphy, Kuh-e Siah was selected which was one of stratigraphy section of Fahliyan Formation. Lower and Upper lithostratigraphic limits were determined by detail field work, 240 samples were collected from selected section; then, thin sections were prepared from each sample for microscopic investigation. According to Abyat et al. (2016) [2] [3], Lopez-Martinez et al. (2015) [5], Krische et al. (2013) [6], Abyat et al. (2012) [2], Petrova et al. (2012) [7], Granier et al. (2011) [8], Turi et al. (2011) [9], Ivanova and Koldzziej (2010) [10], Hossieni and Conrad (2008) [11], Jozsa and Aubrecht (2008) [12], Afghah (2006) [4], Canudo (2002) [13], Danelian et al. (1997) [14], Deloffre (1988) [15] and Dragestan (1982) [16], the foraminifers and calcareous algae were determined. Investigation of foraminifer and calcareous algae stratigraphic distribution led us to established biozones and age deyermination of Fahliyan in Kuh-e-Siah.

\section{Geographical and Geological Setting}

The studied section is located at southwest of Arsanjan (Figure 1). The geographical coordinates (latitude and longitude) of this section are $29^{\circ} 47^{\prime} 52^{\prime \prime} \mathrm{N}$ and $53^{\circ} 12^{\prime} 04^{\prime \prime} \mathrm{E}$, respectively (Figure 2).

Based on Alavi (2004) [17], Zagros is divided into three major structural zones which are Simply-Folde, Imbricated and Metamorphic zones. Kuh-e-Siah stratigraphic section is located in Simply-Folded zone of the Zagros. Actually, structure of the Kuh-e-Siah is referred to an anticline with SW-NE trend similar other structures of the Zagros area 
[18]. It consists of well exposed of Jurassic though Cenomanian sequence (Surmeh, Fahliyan, Gadvan, Dariyan, Kazhdumi and Sarvak formations). Studied section is assigned to Interior Fars area by James and Wynd (1965) [19]. In this section, Fahliyan Formation is encompassed by Surmeh (mid to late Jurassic) and Gadvan (Barremian) continously (Figure 3).

\section{Lithostratigraphic Units}

Fahliyan Formation in Kuh-e-Siah section with the thickness of $345 \mathrm{~m}$ conformably overlies Surmeh formation and is lithologically inseparable; further, it is underlied by the marls of Gadvan formation and covers limestone of Surmeh formation. Lithologically, this rock unit divided into five lithostratigraphic units as follows (Figure 4).

1) The initial $63 \mathrm{~m}$ of this Formation is composed of cream thin-bedded to massivecolored dolomitic limestone with an interbed sandy limestone. This unit continuously lies over the dolomitic limestone of Surmeh Formation (Unit 1).

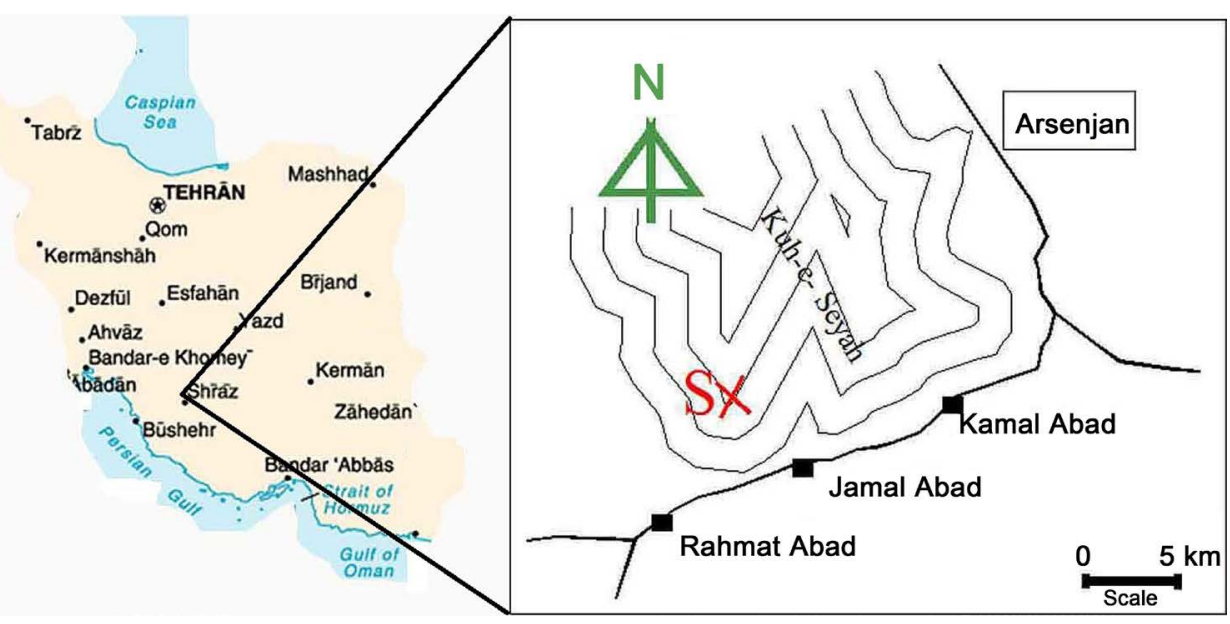

Figure 1. Geographical location of Fahliyan Formation in Kuh-e-Siah section.

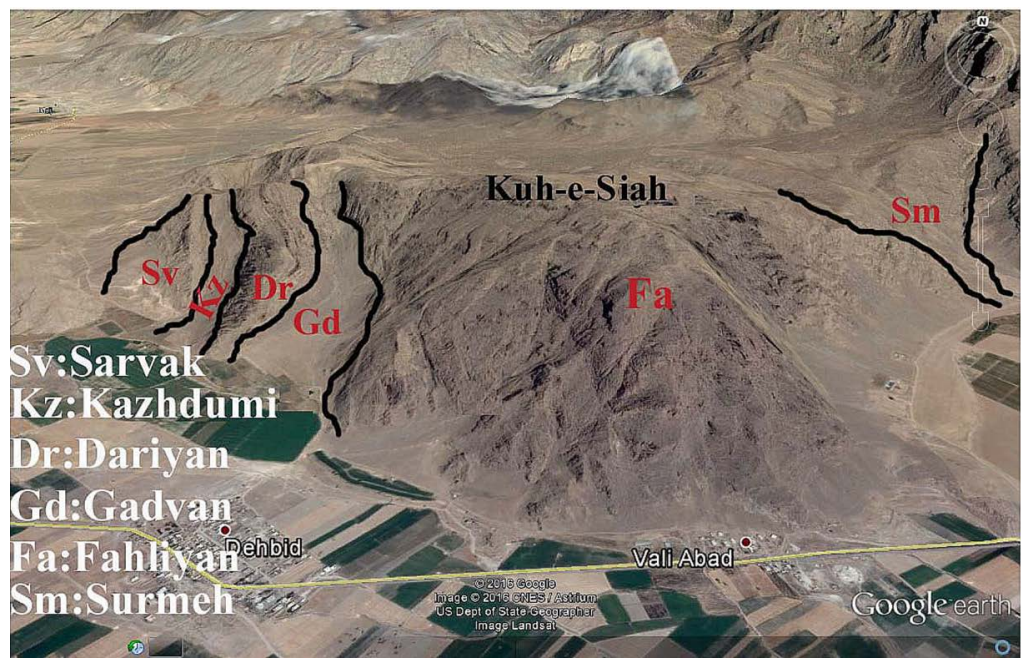

Figure 2. Satellite image of Formations in the region. 


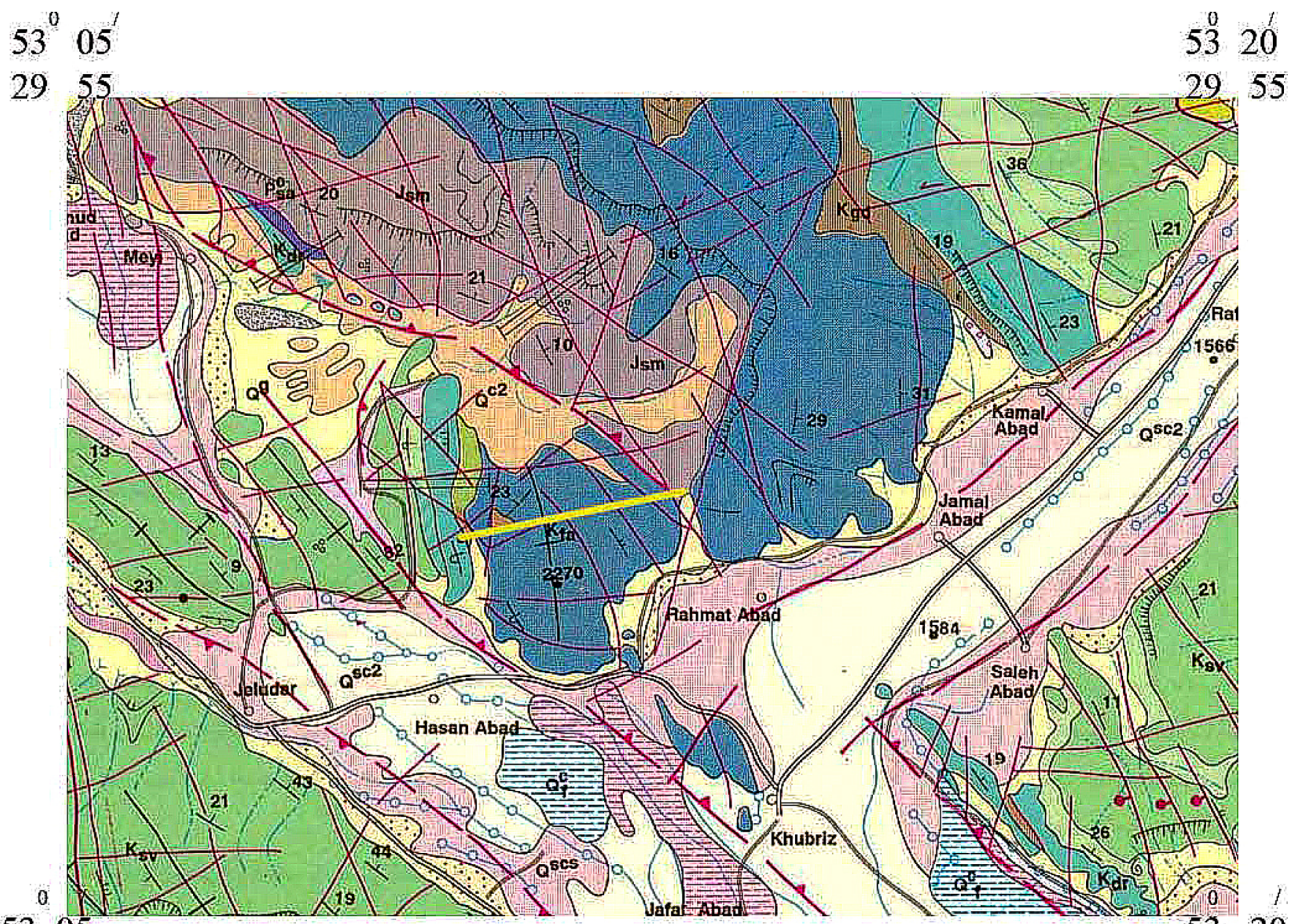

5305

\section{LEGEND}

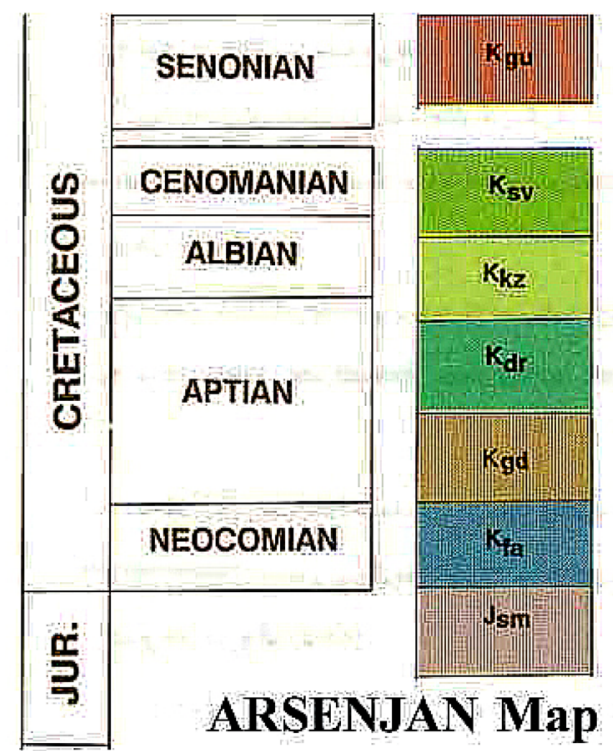

Kgu : Afternation of greenish yellow marl and merlstone, Ijmestone and shale (Gurpl Formation)

$K_{\text {sv }}$ : Medium bedded to messlve gray llmestone (Sarvak Formation)

$K_{k z}$ : Limestone altemating with argilliceous orbholina limestone, shale and marl (Kazduml Formation)

$K_{\mathrm{dr}}$ : Massive to thick - bedded limeston and argillaceous limestone (Dariyan Formation)

$\mathrm{Kgd}:$ Greenish gray to brown marl, shale with interbedded marly Ilmestone, argillaceous limestone and limestone (Gadvan Formation)

$K_{f a}$ : Massive to think - bedded, limestone, argillaceous Iimestone (Fahilyan Formation)

Jsm : Masslve to think bedded limestone, dolomitic limesione argillaceous limestone and dolomite. (Surmeh Formation)

\section{Scale 1:100 000}

Figure 3. Geological map of Fahliyan Formationo utcrop in stratigraphic section of Kuh-e-Siah (adopted from Arsanjan 1/100,000 map, Geological Survey and Mineral Exploration of Iran). 


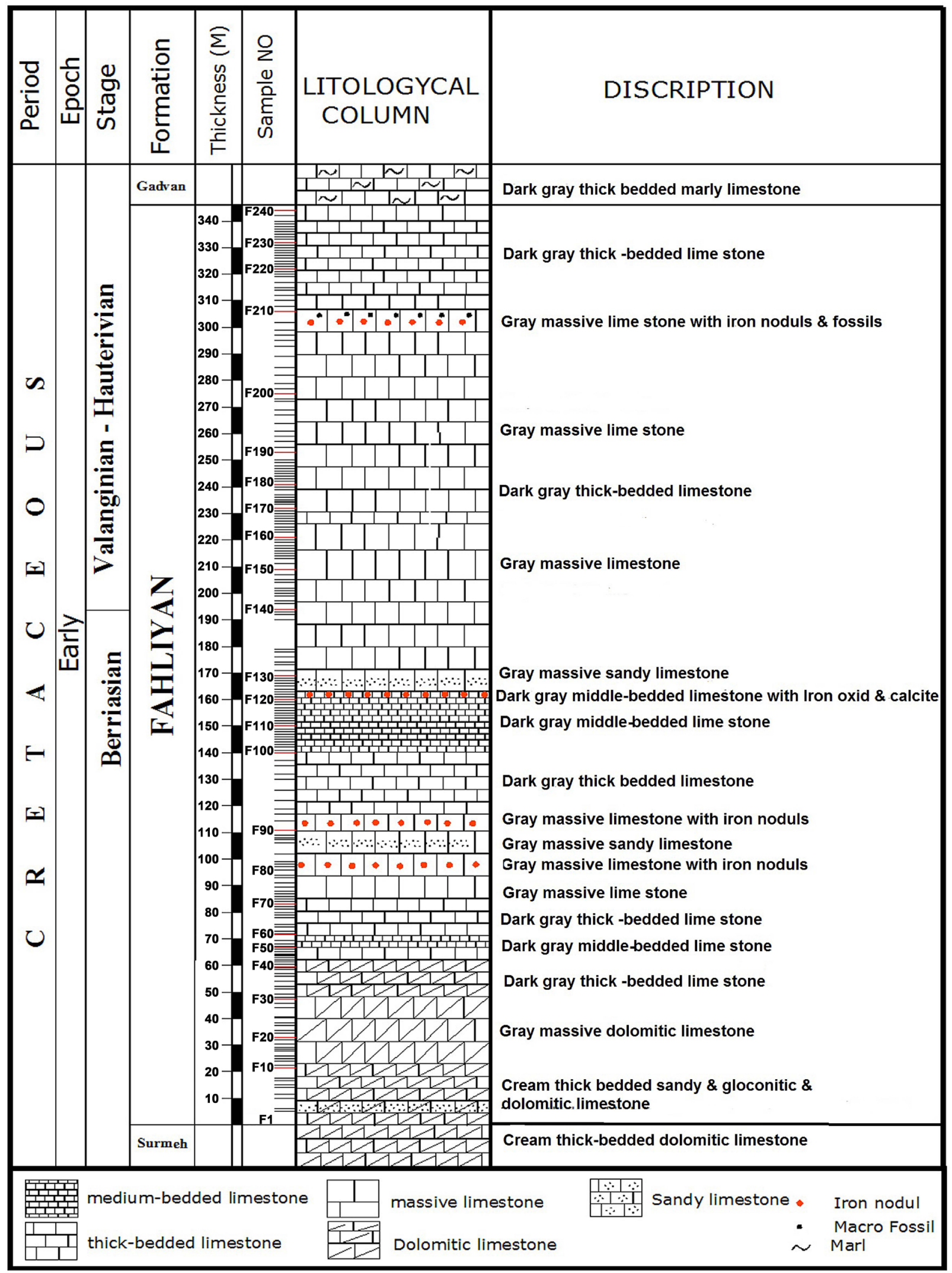

Figure 4. Stratigraphy column of Fahliyan Formation in Kuh-e-Siah section, Arsanjan. 
2) The second unit is described by $77 \mathrm{~m}$ of dark gray thick-bedded to massive limestone with interbeds of sandy limestone and iron nodules.

3) The third unit is covered by $30 \mathrm{~m}$ of dark gray medium-bedded limestone and, in the upper part, sandy limestone along with a small amount of iron nodules (Unit 3). It is better to add Unit 2 and 3 in this form: Alternation of dark gray medium to thick bedded with massive limestone and an interbed sandy limestone which is extended approximately $107 \mathrm{~m}$. This unit overlies the Unit 1 .

4) The Unit 4 is determined by of gray thick to massive Limestone which is measured approximately $128 \mathrm{~m}$.

5) $47 \mathrm{~m}$ of massive gray-colored limestone with iron nodules and it terminates to dark gray thick-bedded to massive limestone (Unit 5) which lies under the marly limestone of Gadvan Formation.

\section{Biostratigraphy and Biozonation}

Stratigraphic distribution of identified foraminifers supports three biozones in the Fahliyan section of Kuh-e-Siah. According to the studies, the last presence of Pfenderina salernitana (Sartonia and Crescenti) is coeval with the first appearance of Calpionella alpina Lorenz which indicates of the Lower biostratigraphic limit of Fahliyan Formation. The upper limit of Fahliyan Formation with Gadvan Formation is identified with to the first occurrence of the Choffatella decipiens Schlumberger that continuously overlies the Fahliyan Formation. Moreover, three biozones have been identified for Fahliyan Formation's sediments in Kuh-e-Siah section, including:

\section{Bizone 1: Calpionella alpina zone}

This zone comprises the lower part of Fahliyan Formation in Kuh-e-Siah section in Arsanjan and immediately overlies the dolomitic limestone sediments of Surmeh Formation. As mentioned before, the first presence of Calpionella alpina Lorenz marks the lower biostratigraphic limit of the Fahliyan Formation which is synchronous with disappearance of Pfenderina salernitana (Sartonia and Crescenti). This zone has is measured approximately $185 \mathrm{~m}$ and is composed of dolomitic limestone and massive limestone with sandy limestone interlayers. The faunal assemblage of this zone consists of:

Calpionella sp., Calpionella oblonga Cadisch, Paleotextolaria sp., Marsonella trochus (D’Orbigny), Marsonella sp., Lenticulina sp., Pseudolithunella sp., Fenestrella dunninington, Elliot, Miliolid, Trocholina sp., Trochulina elongata (Leupold), Trocholina arabica Schlumberger, Praeachrysalidina infracretacea Luperto Sinni, Pseudochrysalidina sp., Nautiloculina oolitica Mohler, Novalesia distorta Arnaud-Vanneau and diagnosed calcareous algae are consisted of Lithocudium aggregatum Elliot, Acicularis sp., Permocalculus inopinatus Elliot.

The age of this zone is determined as Berriasian.

\section{Biozone 2: Pseudochrysalidina conica zone}

This zone is described by disappeared of Calpionella alpina Lorenz which is coeval with of the presence of Pseudochrysalidina conica Henson. This zone has the thickness of $40 \mathrm{~m}$ and comprises of gray massive limestone. It is associated with the following 
species of foraminifera:

Calpionella sp., Calpionella oblonga Cadisch, Crassicollaria colomi Doben, Pseudochrysalidina arabica Henson, Lenticulina sp., Pseudolithunella sp., Miliolid, Trocholina sp., Trocholina elongata (Leupold), Praechrysalidina infracretacea Luperto Sinni, Pseudochrysalidina conica Henson, and calcareous algae Lithocudium aggregatum, Permocalculus inopinatus Elliott.

The foraminiferal assemblage and calcareous algae of this biozone indicates early Valanginian age.

Biozone 3: Pseudocyclammina lituus, Trocholina Assemblage zone

This zone is marked by the first presence of Pseudocyclammina lituus Yokoyama and various taxa of Trocholina. Pseudocyclammina lituus, Trocholina Assemblage zone is bounded by the first occurrence Chofatella decipensis Schlumberger. This zone is $120 \mathrm{~m}$ thick and contains gray thick bedded limestone with interbeds containing abundant iron nodules and fossils. This zone is associated with the following species of foraminifera:

Crassicollaria colomi Doben, Calpionella sp., Marsonella trochus (D'Orbigny), Lenticulina sp., Pseudolithunella sp., Fenestrella sp., Paleogoudyrina sp., Glomospira sp., Miliolid., Trocholina sp., Trocholina elongata (Leupold), Trocholina arabica Schlumberger, Trocholina alpina (Leupold), Trocholina altispira Henson, Praechrysalidina infracretacea Luperto Sinni, Pseudochrysalidina sp., Marsonella sp., Navalesia disorta Arnaud-Vanneau, Hedbergella sigali Moullade, Nautiloculina oolitica Mohler, Gorbachikella sp., and rarely calcareous algae Permocalculus inopinatus Elliot.

According to diagnosed foraminifers and non-foraminifers microfossils the age determination of this biozone is assigned to early Hauterivian age (Figure 5).

\section{Biostratigraphy Consistency of Fahliyan Formation's Biozones in Kuh-E-Siah in Arsanjan with Previous Studies}

Table 1 shows the lower Cretaceous zones based on the studies by Gollesstaneh (1965) [20], Sissigh (1977) [21], Wynd (1965) [22], Afghah (2006) [4] and Abyat (2012) [2]. Accordingly:

- Zone (1) of Fahliyan Formation in Kuh-e-Siah section in Arsenjan called Calpionella alpina zone with the Berriasian age is equivalent to Tintinnid, B1, and Calpionella-Sponge Spicules assemblage zones in Gollesstaneh (1965) [20], Sissigh (1977) [21] and Wynd's (1965) [22] studies.

- Zone (2) of Fahliyan Formation in Kuh-e-Siah section in Arsanjan called Pseudochrysalidina conica with the age of Valangian is equivalent to Tintinnid, B2, and Calpionella-Sponge Spicules assemblage zones in Gollesstaneh (1965) [20], Sissigh (1977) [21] and Wynd's (1965) [22] studies, respectively.

- Zone (3) of Fahliyan Formation in Kuh-e-Siah section in Arsanjan called Pseudocyclammina lituus, Trocholina assemblage zone with the Hauterivian age is equivalent to Pseudocyclammina lituus, Dokhania arabica, Algal Assemblage, B3, and Pseudocyclammina lituus, Trocholina assemblage zones in Gollesstaneh (1965) [20], Sissigh(1977) [21] and Wynd's (1965) [22] studies. 


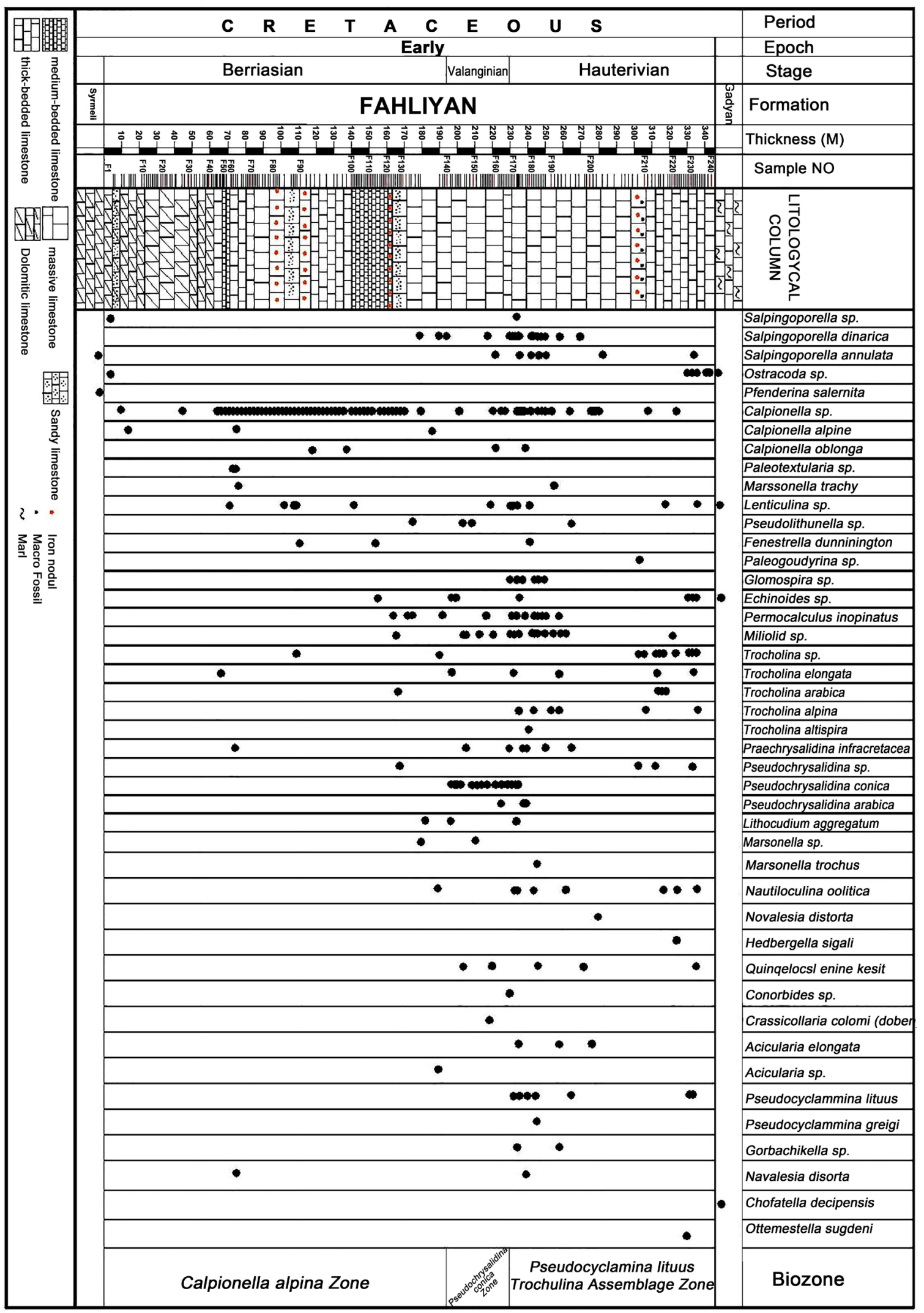

Figure 5. Vertical distribution of foraminifers, calpionelids and calcareous algae of Fahliyan Formation in Kuh-e-Siah section of Arsanjan. 
Table 1. Comparison of Fahliyan Formation's biozones in Kuh-e-Siah section with the studies by Gollesstaneh (1965) [20], Sissigh (1977) [21], Wynd (1965) [22], Afghah (2006) [4] and Abyat et al. (2012) [2].

\begin{tabular}{|c|c|c|c|c|c|c|}
\hline Age & This study & Afghah (2006) & Abyat et al. (2012) & Sissigh (1977) & Gollesstaneh (1965) & James \& Wynd (1965) \\
\hline Hauterivian & $\begin{array}{c}\text { Pseudocyclammina } \\
\text { lituus, Trocholina } \\
\text { Assemblage zone }\end{array}$ & $\begin{array}{l}\text { Pseudocyclammina } \\
\text { lituus zone } \\
\text { Pseudochrysalidina }\end{array}$ & $\begin{array}{c}\text { Pseudocyclammina } \\
\text { lituus zone }\end{array}$ & $B 3$ & $\begin{array}{c}\text { Pseudocyclammina } \\
\text { lituus, Dokhania } \\
\text { arabica, Algal zone III }\end{array}$ & $\begin{array}{l}\text { Pseudocyclammina } \\
\text { lituus, Trocholina } \\
\text { Assemblage zone }\end{array}$ \\
\hline Valanginian & $\begin{array}{l}\text { Pseudochrysalidina } \\
\text { conica zone }\end{array}$ & & & B2 & & \\
\hline Berriasian & $\begin{array}{c}\text { Calpionella alpina } \\
\text { zone }\end{array}$ & $\begin{array}{l}\text { Pseudocyclammina } \\
\text { greigi zone } \\
\text { \&(Trocholina alpine } \\
\text { sub zone) } \\
\text { Calpionella alpina } \\
\text { zone }\end{array}$ & $\begin{array}{l}\text { Dokhania zone } \\
\text { Tintinnid zone }\end{array}$ & $B 1$ & Tintinnid zone III & $\begin{array}{c}\text { Calpionella, Spiculs } \\
\text { assemblage zone }\end{array}$ \\
\hline
\end{tabular}

Generally, comparing of established biozone of Fahliyan Formation in Kuh-e-Siah with previous work is summarized in Table 1. Biostratigraphic studies confirm shallow water paleoenvionment during Valenginain-Hauterivian age whereas the established biozones of Beriassian support open marine to shallow water depositional system. However, the biostratigraphic study on lower contact of the Fahliyan Formation indicates continuous sedimentation during Jurassic/Cretaceous boundary. Moreover the Calpionelids were recorded in many previous works (e.g. Abyat et al. (2012) [2], Afghah (2006) [4], Gollesstaneh (1965) [20] and Wynd (1965) [22]). Therefore, open marine paleoenvironment are recognized in Beriassian age. Since many of studied section of Fahliyan Formation are located in Coastal and Interior Fars regions, the Calpionellids are well distributed along the mentioned areas. Stratigraphic distribution of faunal assemblage of the Fahliyan sections supports a regression during Neocomian time. Generally the mention regression is recorded by the beginning of Valanginian time Abyat et al. (2012) [2] which is concordance with the present study. Afghah (2006) [4] and Kalantari (1976) [23] reported the regression in late Beriassian by the presence of Pseudocyclammina greigi (Henson) whereas Gollesstaneh (1965) [20] and Wynd (1965) [22] suggested the regression record to Hautrivian age. In addition sea-level fluctuation of lower Cretaceous confirms heterochronous event in various stratigraphic sections of the Zagros area. All documents show the presence of Pseudocyclammina lituus Yokoyama in upper biostratigraphic limit of Fahliyan Formation as described zone. Many studies revealed the disappearance of this taxon is synchronous with the first presence of Choffatella decipiens. Schlumberger previous biostratigraphic data reflected that the presence of the mentioned taxon is distinguished in the lowermost lithostratigraphic limit of of Gadvan Formation. But new biostratigraphic record Afghah et al. (2016) [24] supports the stratigraphic distribution of Psedocyclammina lituus Yokoyama is extended to some part of lower lithostratigraphic of Gadvan Formation in Table 1 and Figure 6. 


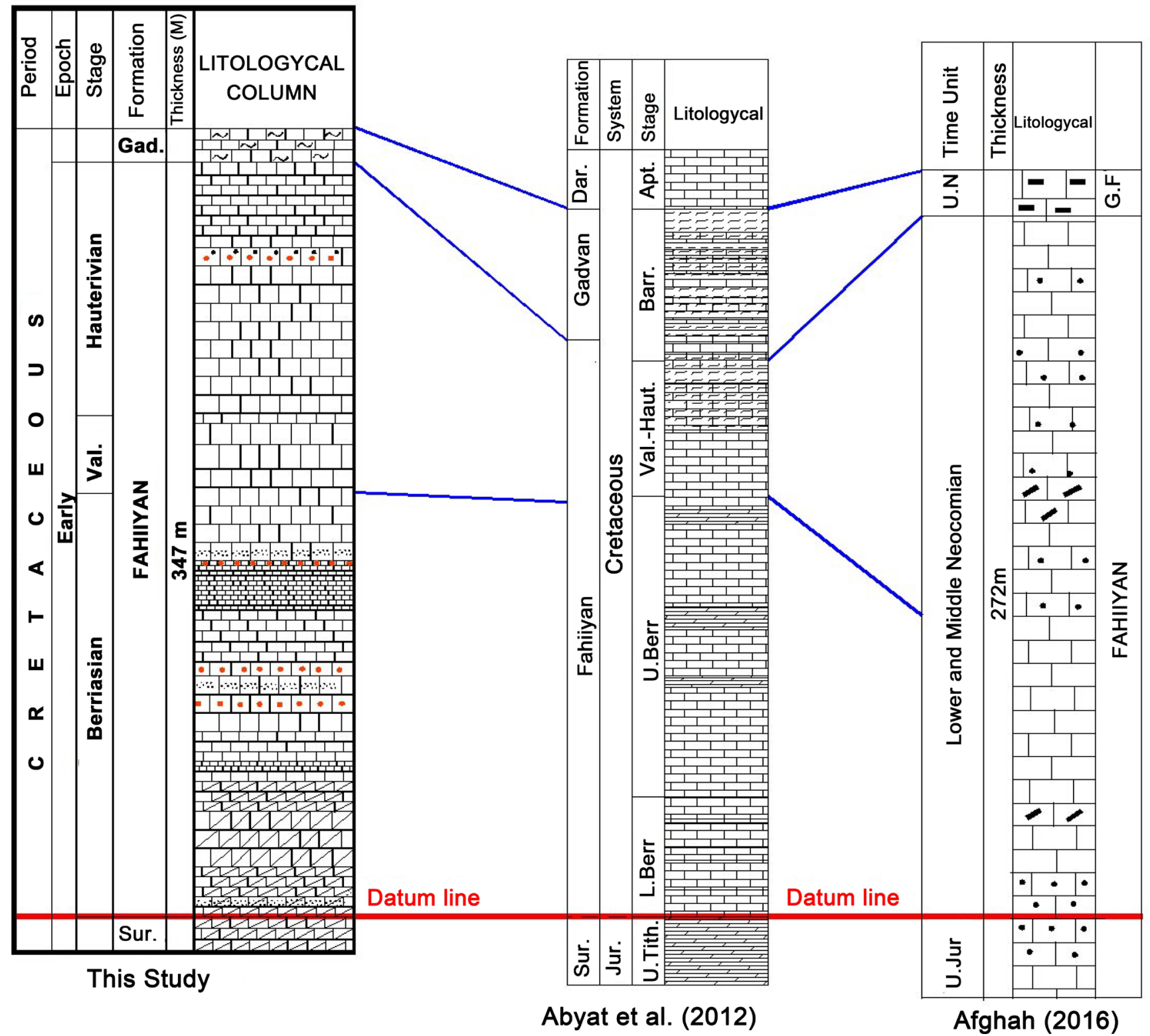

Figure 6. Comparing Fahliyan Formation in Kuh-e-Siah section with the studies by Afghah (2006) [4] and Abyat (2012) [2].

\section{Conclusions}

Biozonation of the Zagros lower Cretaceous strata is mainly established by foraminifers and Calpionelids. By the present study, disconformity is not recognized between Jurassic/Cretaceous boundaries. Vertical distribution of Pseudocyclammina lituus Yokoyama is similar with other previous records of Zagros Neocomian succession.

Regression of Neocomian time can be assigned to global tectonic movement of Upper Jurassic which is distinguishable in many geologic zones of Iran Aghanabati (1988) [1]. Actually the mentioned tectonic setting causes of break in sedimentation and angular unconformity in other zones of Iran. Deep water depositional system of Zagros is a proof which does not show hiatus between Jurassic/Cretaceous boundaries. 


\section{References}

[1] Aghanabati, A. (1998) Jurassic Stratigraphy of Iran. Geological Survey of Iran, Tehran, 746 p. (In Persian)

[2] Abyat, A., Baghbani, D., Afghah, M., Ghadimvand, K.N. and Feghi, A. (2012) Microbiostratigraphy and Lithostratigraphy of Fahliyan and Gadvan Formations in Kuh-e-Surmeh (Zagros Basin, Southwest Iran). Advances in Environmental Biology, 6, 3078-3086.

[3] Abyat, A., Baghbani, D., Afghah, M., Afsari, S. and Ghadimvand, K.N. (2016) NeocomianBarremian Foraminifers and Algae from Coastal Fars (South Iran). Arabian Journal of Geosciences, 9, 262. https://doi.org/10.1007/s12517-015-2128-5

[4] Afghah, M. (2006) Microbiostratigraphy of Fahliyan Formation in Kuh-e-Gadavan and Ab Siah. JSIAU, 61, 89-107.

[5] Lopez-Martinez, R., Barragan, R. and Rehakova, D. (2015) Calpionellid Biostratigraphy across the Jurassic/Cretaceous Boundary in San José de Iturbide, Nuevo León, Northeastern Mexico. Geological Quarterly, 59, 581-592.

[6] Krische, O., Bujtor, L. and Gawlick, H. (2013) Calpionellid and Ammonite Biostratigraphy of Uppermost Jurassic to Lower Cretaceous Sedimentary Rocks from the Leube Quarry (Northern Calcareous Alps, Salzburg, Austria). Austrian Journal of Earth Sciences, 106, 2645 .

[7] Petrova, S., Rabrenović, D., Lakova, I., Koleva-Rekalova, E., Ivanova, D., Metodiev, L. and Malešević, N. (2012) Biostratigraphy and Microfacies of the Pelagic Carbonates across the Jurassic/Cretaceous Boundary in Eastern Serbia (Stara Planina-Poreč Zone). Geologica Balcanica, 41, 53-76.

[8] Granier, B. and Bucurm, I. (2011) Stratigraphic Ranges of Some Tithonian-Berriasian Benthic Foraminifers and Dasycladales. Re-Evaluation of Their Use in Identifying This Stage Boundary in Carbonate Platform Settings. Boletín del Instituto de Fisiografía y Geología, 79-81, 9-10.

[9] Turi, V., Săsăran, E. and Bucur, I. (2011) New Data on the Upper Jurassic-Lower Cretaceous Limestones from Bihor Mountains: Case Study of Gârda Seacă-Hodobana Region, Romania. Studia UBB Geologia, 56, 11-27. https://doi.org/10.5038/1937-8602.56.1.2

[10] Ivanova, D. and Kołodziej, B. (2010) Late Jurassic-Early Cretaceous Foraminifera from S tramberk-Type Limestones, Polish Outer Carpathians. Studia UBB Geologia, 55, 3-31. https://doi.org/10.5038/1937-8602.55.2.1

[11] Hosseini, S.A. and Conrad, M.A. (2008) Calcareous Algae, Foraminifera and Sequence Stratigraphy of the Fahliyan Formation at Kuh-e-Surmeh (Zagros Basin, SW of Iran). Geologia Croatica, 61, 215-237.

[12] Jozas, Š. and Aubrecht, R. (2008) Barremian-Aptian Erosion of the Kysuca-Pieniny Trough Margin (Pieniny Klippen Belt, Western Carpathians). Geologica Carpatica, 59, 103-116.

[13] Canudo, J.I. (2002) Chapter 13: Tintínidos. In: Molina, E., Ed., Eustoquio MOLINA, Univesidad de Zaragoza, Espana, 265-280.

[14] Danelian, T., De Wever, P. and Azema, J. (1997) Palaeoceanographic Significance of New and Revised Palaeontological Datings for the Onset of Vigla Limestone Sedimentation in the Ionian Zone of Greece. Geological Magazine, 134, 869-872. https://doi.org/10.1017/S0016756897007553

[15] Deloffre, R. (1988) Nouvelle taxonomie des algues dasycladales. Bulletin des Centres de Recherches Exploration-Production Elf-Aquitaine, 12, 165-217.

[16] Dragstan, O. (1982) Lower Cretaceous Marine Algae and Calpionellida from Canada (San- 
pedro)-Asturisa Province (Spain). Cuadernos Geología Ibérica, 8, 125-143.

[17] Alavi, M. (2004) Regional Stratigraphy of the Zagros Fold-Thrust Belt of Iran and Its Proforeland Evolution. American Journal of Science, 304, 1-20.

https://doi.org/10.2475/ajs.304.1.1

[18] Berberian, M. and King, G.C.P. (1981) Towards the Paleogeography and Tectonic Evolution of Iran. Canadian Journal of the Earth Sciences, 18, 210-265. https://doi.org/10.1139/e81-019

[19] James, G.A. and Wynd, J.G. (1965) Stratigraphical Nomenclature of Iranian Oil Onsortium Agreement Area. American Association of Petroleum Geologists Bulletin, 49, 2182-2245.

[20] Gollesstaneh, A. (1965) Micropalaeontological Study of the Upper Jurassic and Lower Cretaceous of Southern Iran. Unpublished PhD Thesis, University of London, London, 629.

[21] Sissigh, W. (1977) Biostratigraphy of Cretaceous Calcareous Non-Nopiancton. Geologie en Mijnbouw, 56, 37-65.

[22] Wynd, J.G. (1965) Biofacies of the Iranian Oil Consortium Agreement Area: Iranian Oil Operating Companies. Geological and Exploration Division Report 1082, 89.

[23] Kalantari, A. (1975) Microbiostratigraphy of the Sarvestan Area Southwestern Iran. National Iranian Oil Company, Geological Aboratories, Pub. No. 5, 129.

[24] Afghah, M., Abtahian, A. and Saberi, A. (2016) Foraminiferal Biostratigraphy of Early Cretaceous (Hauterivian-Barremian) Sediments of the Zagros Basin (SW of Iran). Journal of African Earth Sciences, 121, 42-55. https://doi.org/10.1016/j.jafrearsci.2016.05.010 


\section{Appendix Plates}
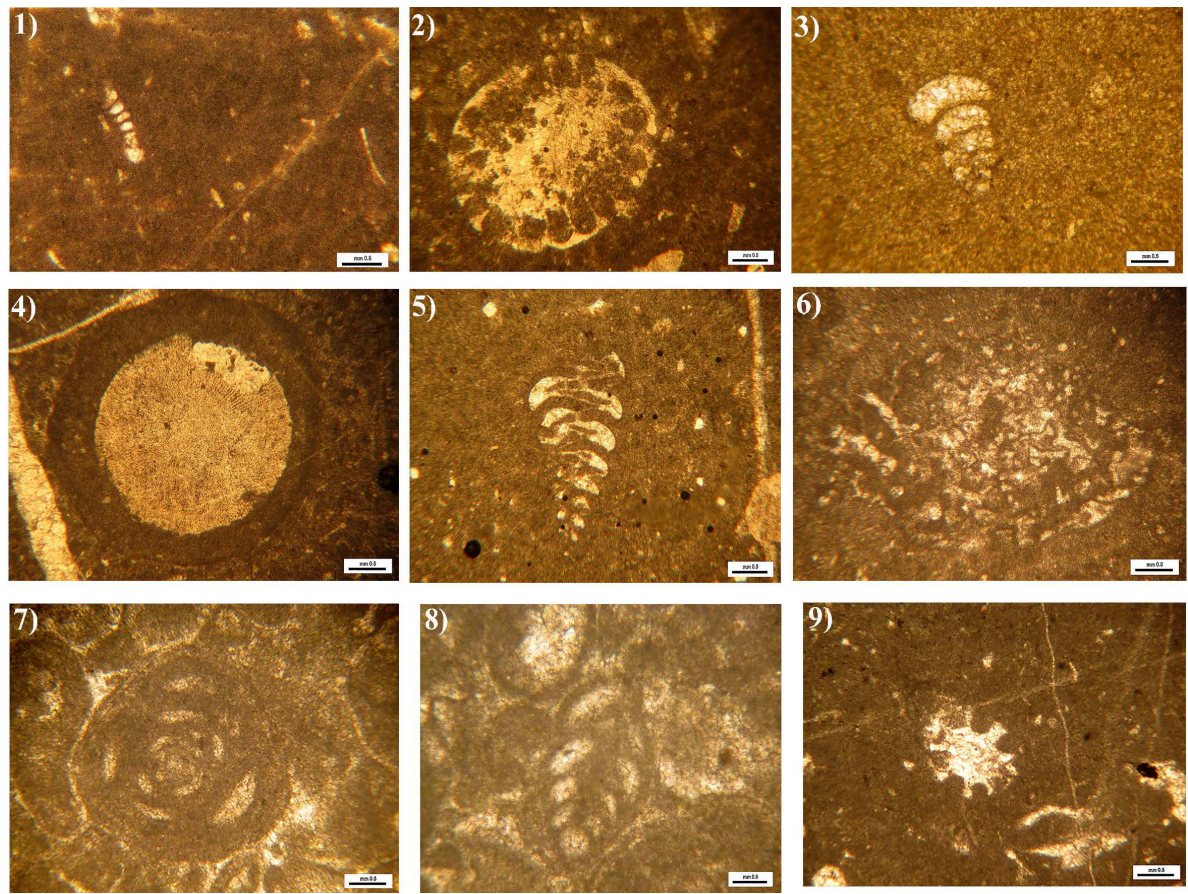

Plate 1. (1) Pfenderina salernitana; (2) Clypeina solkani; (3) Praechrysalidina infracretacea; (4) Permocalculus innopinatus; (5) Pseudochrtsalidina conica; (6) Pseudocyclamina lituus; (7) Quinqueloculina; (8) Siphoalveolina sp.; (9) Terqumella sp.
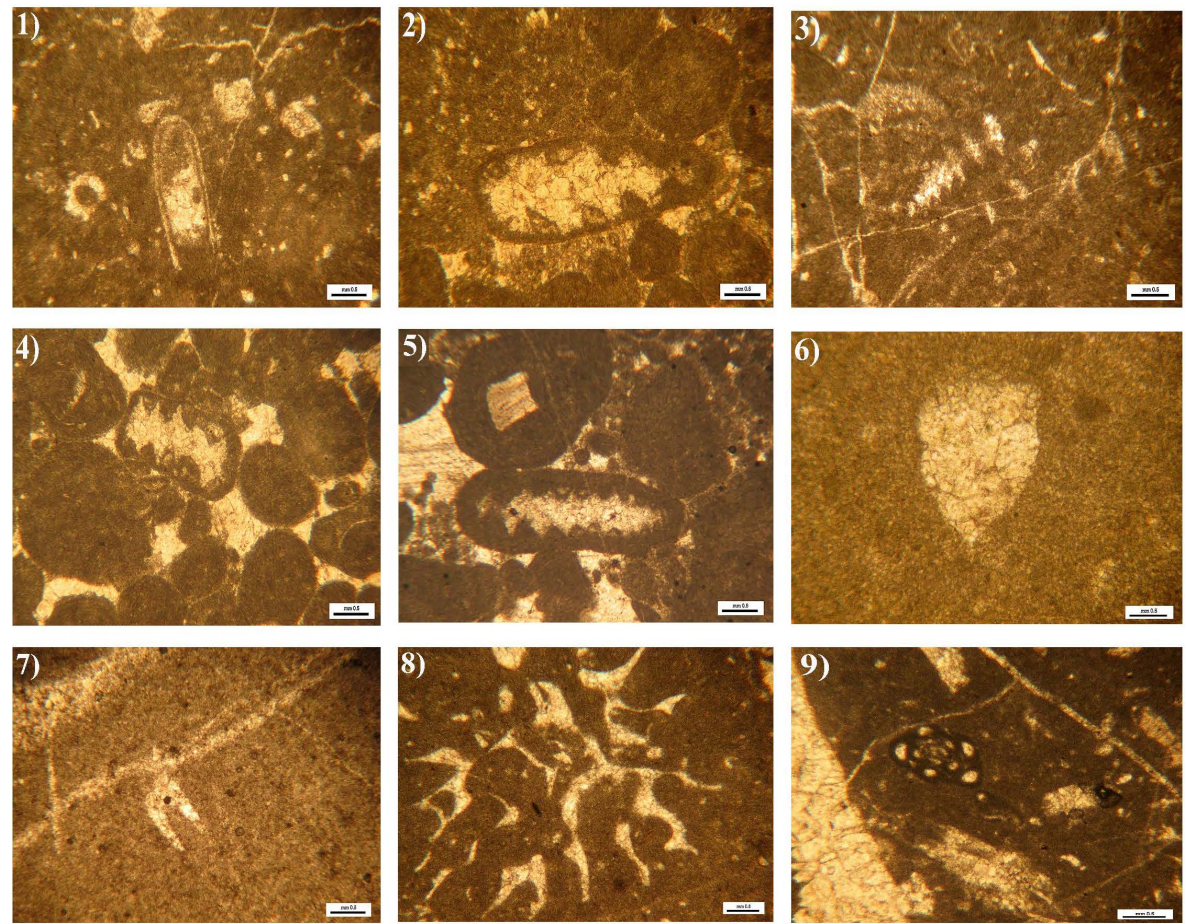

Plate 2. (1) Tintinolina campanella; (2) Trocholina alpine; (3) Trocholina Arabica; (4) Trocholina campanella; (5) Trocholina elongate; (6) Calpionella alpine; (7) Calpionella oblonga; (8) Clypeina jurassica; (9) Glomospina neocomian. 

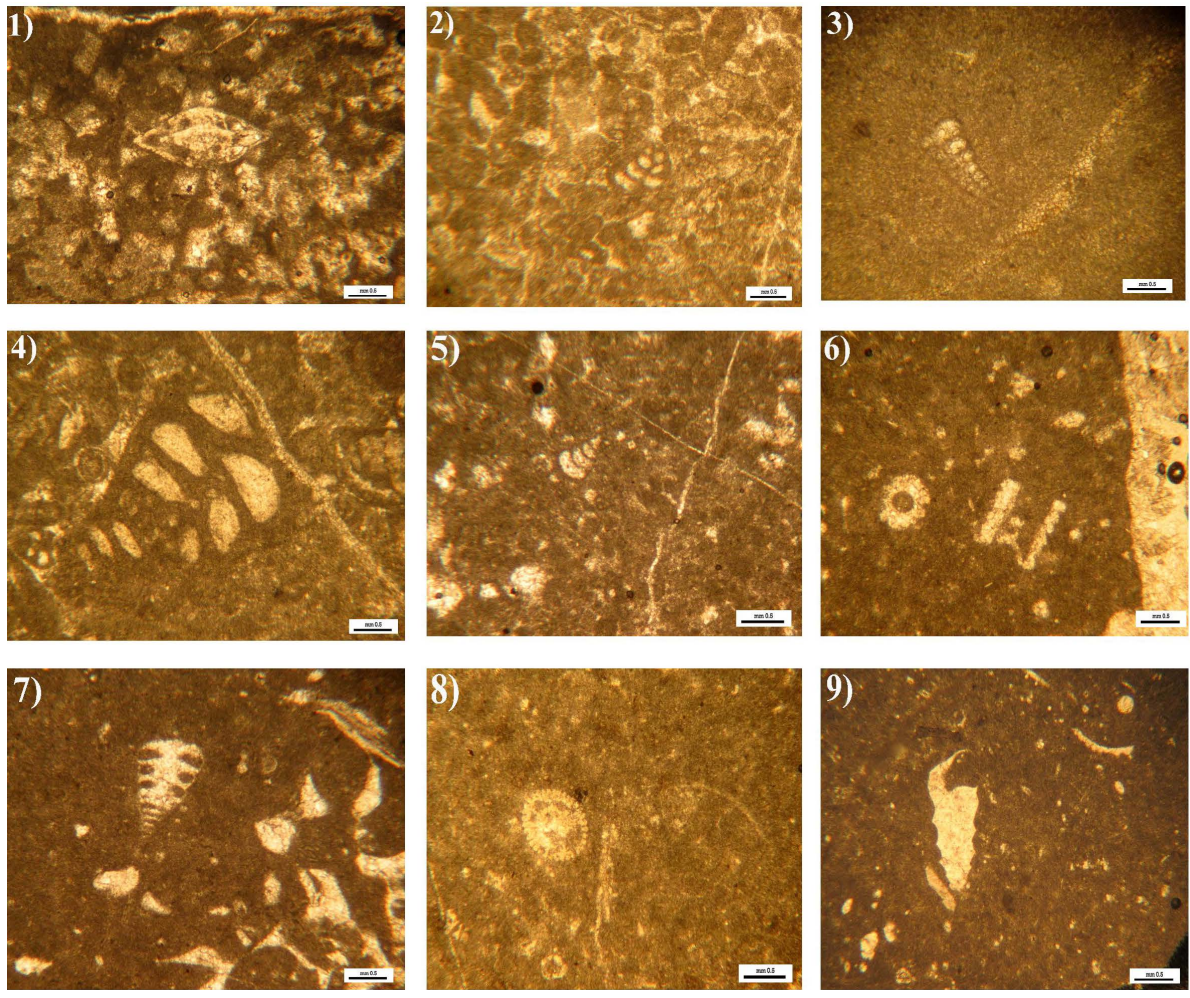

Plate 3. (1) Lenticulina sp.; (2) Marsonella trochus; (3) Paleotextolaria sp.; (4) Praechrysalidina infracretacea; (5) Pseudolithunella sp.; (6) Salpingoporella annulata; (7) Salpingoporella dinarica; (8) Trocholina companella; (9) Trocholina elongate.

Submit or recommend next manuscript to SCIRP and we will provide best service for you:

Accepting pre-submission inquiries through Email, Facebook, LinkedIn, Twitter, etc.

A wide selection of journals (inclusive of 9 subjects, more than 200 journals)

Providing 24-hour high-quality service

User-friendly online submission system

Fair and swift peer-review system

Efficient typesetting and proofreading procedure

Display of the result of downloads and visits, as well as the number of cited articles

Maximum dissemination of your research work

Submit your manuscript at: http://papersubmission.scirp.org/

Or contact ojg@scirp.org 